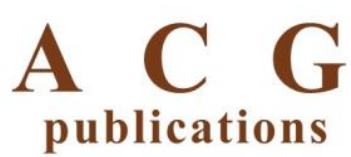

Rec. Nat. Prod. 13:6 (2019) 440-445

records of natural

products

\title{
A New Aporphine Alkaloid from Illigera aromatic
}

\author{
Kuiwu Wang ${ }^{*}, 1$, Xiaoxin Wang ${ }^{1}$, Haijiang Zhang ${ }^{2}$ and Yichao Ge ${ }^{3}$ \\ ${ }^{I}$ School of Food Science and Biotechnology, Zhejiang Gongshang University, Hangzhou, 310018, \\ P.R. China \\ ${ }^{2}$ Jiangsu Key Laboratory of Regional Resource Exploitation and Medicinal Research, Huaiyin \\ Institute of Technology, Huaian 223003, P. R. China \\ ${ }^{3}$ Ocean College, Zhejiang University, Hangzhou 310058, P. R. China
}

(Received November 02, 2018; Revised December 05, 2018; Accepted January 25, 2019)

\begin{abstract}
Chemical investigation of the aerial part of Illigera aromatic S.Z. Huang \& S.L. Mo has resulted in the isolation and characterization of one new aporphine alkaloid, illigerine B (1), along with three known analogues laurodionine B (2), $N$-formyl-laurolitsine (3) and illigerine A (4). Their structures were established by spectrometric means and physico-chemical properties. The in vitro cytotoxic activities of compound 1 against Hela, SMMC7721, and Bcap37 cell lines were evaluated. Compound 1 exhibited moderate cytotoxic activity against the three tumor cell types, with $\mathrm{IC}_{50}$ values of $12.40 \pm 0.78,32.61 \pm 2.05$, and $28.69 \pm 1.80 \mu \mathrm{g} / \mathrm{mL}$. This work shown that aporphine alkaloids might be useful as characteristic markers in chemotaxonomic research of the genus Illigera.
\end{abstract}

Keywords: Hernandiaceae; Illigera aromatic; aporphine alkaloid; Illigerine B; cytotoxicity. ㄷ 2019 ACG Publications. All rights reserved.

\section{Introduction}

Aporphines derivatives are widely distributed in plants of the family Hernandiaceae. Many of these isolates exhibit diversified biological activities, including cytotoxic, vasorelaxing, anti-platelet aggregation, antioxidant, and antiplasmodial properties [1-7]. Illigera aromatica S. Z. Huang \& S. L. Mo (Hernandiaceae) is a small liana distributed mainly in Guangxi and Yunnan provinces, P. R. China. The stems are used medicinally to treat coughs, rheumatic arthralgia, indigestion, and injuries from falls [8]. Previous chemical research on this plant led to the isolation of some aporphines and oxoaporphines [6,7]. In this study, we reinvestigated the aerial part of the plant $I$. aromatica, which was collected in Nanning, Guangxi Province, P. R. China. One new compound aporphine alkaloid, illigerine B (1) (Figure 1), along with three known compounds laurodionine B (2), $N$-formyllaurolitsine (3) and illigerine A (4) were isolated from this species. The in vitro cytotoxic activities of the new compound against Hela, SMMC7721, and Bcap37 cell lines were also reported.

\footnotetext{
*Corresponding author: E-Mail: wkwnpc@zjgsu.edu.cn 
<smiles>O=C1N[C@H]2Cc3cc4c(cc3-c3c5c(cc(c32)[C@H]1O)OCO5)OCO4</smiles>

1<smiles>COc1cc2c(cc1O)CC1c3c(cc(O)c(OC)c3-2)CCN1C=O</smiles>

3<smiles></smiles>

2<smiles>O=C1Nc2cc3cc4c(cc3c3c5c(cc1c23)OCO5)OCO4</smiles>

4

Figure 1. The chemical structures of compounds 1-4.

\section{Materials and Methods}

\subsection{Plant Material}

The aerial part of the plant Illigera aromatica S.Z. Huang \& S.L. Mo was collected on Oct. 2015 in Nanning, Guangxi Province, P. R. China. A voucher specimen (IA-20151001) was identified by Prof. Bin Wu of Zhejiang University, and maintained in the School of Food Science and Biotechnology, Zhejiang Gongshang University, Hangzhou, P. R. China.

\subsection{General Experimental Procedures}

Melting point (uncorrected), BUCHI M565 instrument; IR spectrum (KBr), NicoletAvatar-360 FTIR spectrometer; 1D, 2D NMR, Bruker AVANCE DMX 500 NMR spectrometer $\left({ }^{1} \mathrm{H}\right.$ NMR (500 $\mathrm{MHz})$ and ${ }^{13} \mathrm{C}$ NMR $(125 \mathrm{MHz})$ with TMS as internal standard, $\left.25^{\circ} \mathrm{C}\right)$; HR-ESI-MS, Agilent 6210 TOF-MS spectrometer equipped with an ESI source; ESI-MS, Thermo LCQ Fleet ion trap mass spectrometer. TLC was performed using Merck pre-coated plates ( $\mathrm{Si}$ gel $\left.60 \mathrm{~F}_{254}\right)$ of $0.25 \mathrm{~mm}$ thickness.

\subsection{Extraction and Isolation}

The shade-dried, powdered aerial part of the plant Illigera aromatica $(25 \mathrm{~kg})$ were extracted at room temperature three times with methanol $(3 \times 50 \mathrm{~L})$. The extracts were evaporated in vacuo to afford a gummy residue (1200 g). This residue was partitioned in $\mathrm{H}_{2} \mathrm{O}$ and extracted with EtOAc $(3 \times$ $10 \mathrm{~L})$ and $n$-butanol $(3 \times 10 \mathrm{~L})$, successively. The EtOAc extract $(293 \mathrm{~g})$ was adsorbed onto silica gel $(300 \mathrm{~g})$ and subjected to chromatography over silica gel $(80 \times 1000 \mathrm{~mm}, 100-200 \mathrm{mesh})$, eluting with petroleum ether (PE)/EtOAc gradient mixtures. Eleven main fractions $(F r .1 \sim F r .11)$ were obtained by checking with TLC and combined. Small samples of the fractions were detected by Dragendorff's reagent, with gum obtained from the $F r .7$ and $F r .8$ showing positive reaction. $F r .8$ was subjected to 
chromatography over silica gel $(40 \times 300 \mathrm{~mm}, 300 \mathrm{~g}, 200-300$ mesh $)$, eluting with $\mathrm{CH}_{2} \mathrm{Cl}_{2} / \mathrm{MeOH}$ gradient mixtures to afford 14 subfractions (S-Fr. 8-1 S-Fr. 8-14). S-Fr. 8-14 was subjected to Sephadex LH-20 $(20 \times 1000 \mathrm{~mm}$, Amersham) column and eluted with $\mathrm{MeOH}$ to yield $1(4.7 \mathrm{mg})$. Fr. 7 was further-separated on a silica gel column $(45 \times 600 \mathrm{~mm}, 200-300 \mathrm{mesh})$, eluted with PE-EtOAc (1:1) to give 3 sub-fractions (S-Fr. 7-1 S-Fr. 7-3). S-Fr. 7-1 and S-Fr. 7-2 were re-purified to obtain compounds laurodionine B $(2,5.8 \mathrm{mg})$ and $N$-formyl-laurolitsine $(3,4.5 \mathrm{mg}) . \mathrm{S}-F r .7-3$ was repurified on silica gel column $(25 \times 500 \mathrm{~mm}, 200-300 \mathrm{mesh})$, eluted with PE-EtOAc (5:1-1:1) to give compound illigerine $\mathrm{A}(\mathbf{4}, 1.8 \mathrm{mg})$.

\subsection{Spectroscopic Data}

Illigerine $B(1)$ : Yellowish-orange powder. MP: $246-250{ }^{\circ} \mathrm{C}$. UV (MeOH): $\lambda_{\max }(\log \epsilon): 241(4.38)$, 285 (3.31), 312 (4.25) nm. IR (KBr): $v_{\text {max }}^{\mathrm{KBr}}$ 3431, 3176, 2926, 1664, 1502, 1460, 1400, 1246, 1061, 1039, 941, 852, $569 \mathrm{~cm}^{-1} .{ }^{1} \mathrm{H}$ and ${ }^{13} \mathrm{C}$ NMR (DMSO- $d_{6}$ ): Table 1. ESI-MS: $\mathrm{m} / z=362[\mathrm{M}+\mathrm{Na}]^{+}, 338$ $[\mathrm{M}-\mathrm{H}]^{-}, 320\left[\mathrm{M}-\mathrm{H}-\mathrm{H}_{2} \mathrm{O}\right]^{-}\left(\mathrm{MS}^{2}\right), 290\left[\mathrm{M}-\mathrm{H}-\mathrm{H}_{2} \mathrm{O}-\mathrm{CH}_{2} \mathrm{O}\right]^{-}\left(\mathrm{MS}^{3}\right), 260\left[\mathrm{M}-\mathrm{H}-\mathrm{H}_{2} \mathrm{O}-\mathrm{CH}_{2} \mathrm{O}-\mathrm{CH}_{2} \mathrm{O}\right]^{-}\left(\mathrm{MS}^{4}\right)$, 232 [M-H- $\left.\mathrm{H}_{2} \mathrm{O}-\mathrm{CH}_{2} \mathrm{O}-\mathrm{CH}_{2} \mathrm{O}-\mathrm{CO}\right]^{-}\left(\mathrm{MS}^{5}\right)$. HR-ESI-MS: $\mathrm{m} / z[\mathrm{M}+\mathrm{Na}]^{+}$calcd for $\mathrm{C}_{18} \mathrm{H}_{13} \mathrm{NO}_{6}+\mathrm{Na}^{+}$, 362.0635; found: 362.0627. Yield: $0.002 \%$.

\subsection{Cytotoxic Assay}

The in vitro bioactivity of compounds 1-4 against three tumor cell lines: human cervical carcinoma cells (Hela), human hepatic carcinoma cells (SMMC7721), and human breast cancer cells (Bcap37) were assayed by the MTT method, and cisplatin was used as a positive control (Table 2). The tumor cells were cultured at $37^{\circ} \mathrm{C}$ under a humidified atmosphere of $5 \% \mathrm{CO}_{2}$ in RPMI-1640 medium supplemented with $10 \%$ fetal calf serum, and dispersed in replicate 96 -well plates $\left(1 \times 10^{4}\right.$ cells/well) for $48 \mathrm{~h}$. Compounds 1-4 $(10-200 \mu \mathrm{M})$, or cisplatin (DDP positive control), were then added. After $72 \mathrm{~h}$ of exposure to the testing agents, the cell viability was determined by the MTT by recording the absorbance at $\lambda \max 570 \mathrm{~nm}$ with an ELISA reader. Each test was performed in triplicate $(\mathrm{n}=3)$. The dose resulting in $50 \%$ inhibition of cell growth, $\mathrm{IC}_{50}$, was calculated by NDST software. The data were expressed as mean \pm standard deviation (S.D.) $[10,11]$.

\section{Results and Discussion}

\subsection{Structure Elucidation}

Compound 1 was obtained as a yellowish-orange powder and its molecular formula was deduced to be $\mathrm{C}_{18} \mathrm{H}_{13} \mathrm{NO}_{6}$ by HR-ESI-MS at $m / z 362.0627[\mathrm{M}+\mathrm{Na}]^{+}$(calcd. for $\mathrm{C}_{18} \mathrm{H}_{13} \mathrm{NO}_{6}+\mathrm{Na}^{+}, 362.0635$ ), with an unsaturation degree of thirteen. The IR absorption band at 3424, 3176, 1664, and $1400 \mathrm{~cm}^{-1}$ suggested the presence of hydroxyl and amide groups. The UV spectrum showed absorption maxima at 241, 285 and $312 \mathrm{~nm}$. The ${ }^{1} \mathrm{H},{ }^{13} \mathrm{C}$ NMR and HSQC spectra of 1 (Table 1) displayed the characteristic NMR features for an aporphine alkaloid bearing two benzene rings $\left(\delta_{\mathrm{H}} 7.52(\mathrm{~s}), 6.97(\mathrm{~s})\right.$, and $6.85(\mathrm{~s}) ; \delta_{\mathrm{C}} 143.5(\mathrm{~s}), 115.3(\mathrm{~s}), 147.8(\mathrm{~s}), 107.7(\mathrm{~d}), 129.0(\mathrm{~s}), 126.0(\mathrm{~s}), 128.7(\mathrm{~s}), 109.5(\mathrm{~d})$, $147.2(\mathrm{~s}), 146.9(\mathrm{~s}), 107.0(\mathrm{~d})$ and $124.0(\mathrm{~s}))$, two $-\mathrm{OCH}_{2} \mathrm{O}-$ units $\left(\delta_{\mathrm{H}} 6.19(\mathrm{~s}), 6.06(\mathrm{~s})\right.$ corresponding to $\delta_{\mathrm{C}} 101.7(\mathrm{t}) ; \delta_{\mathrm{H}} 6.05(\mathrm{~s}), 6.04(\mathrm{~s})$ corresponding to $\left.\delta_{\mathrm{C}} 101.8(\mathrm{t})\right)$, an amide group $\left(\delta_{\mathrm{H}} 8.35(\mathrm{~s}, \mathrm{NH}) ; \delta_{\mathrm{C}}\right.$ $170.2(\mathrm{~s}))$, an methylene $\left(\delta_{\mathrm{H}} 2.56(\mathrm{dd}, J=14.15,14.55 \mathrm{~Hz}), 3.04(\mathrm{dd}, J=5.20,14.55 \mathrm{~Hz}) ; \delta_{\mathrm{C}} 36.3(\mathrm{t})\right)$, an methine $\left(\delta_{\mathrm{H}} 4.50(\mathrm{dd}, J=5.20,14.15 \mathrm{~Hz}) ; \delta_{\mathrm{C}} 50.1(\mathrm{~d})\right)$, and an oxysubstituted methine $\left(\delta_{\mathrm{H}} 4.61(\mathrm{~d}, J\right.$ $\left.=5.90 \mathrm{~Hz}) ; \delta_{\mathrm{C}} 68.3(\mathrm{~d})\right)$. Thus, 1 was deduced to have an aporphine skeleton [7, 9], with two methylenedioxy and one hydroxyl substituent groups. The low resolution negative electrospray ionization tandem mass spectrometry spectra (S3-S7) of compound 1 showed $\mathrm{m} / z 338[\mathrm{M}-\mathrm{H}]^{-}$and fragment ions at $\mathrm{m} / z 320\left[\mathrm{M}-\mathrm{H}-\mathrm{H}_{2} \mathrm{O}\right]^{-}\left(\mathrm{MS}^{2}\right), 290\left[\mathrm{M}-\mathrm{H}^{2} \mathrm{H}_{2} \mathrm{O}-\mathrm{CH}_{2} \mathrm{O}\right]^{-}\left(\mathrm{MS}^{3}\right), 260\left[\mathrm{M}-\mathrm{H}-\mathrm{H}_{2} \mathrm{O}-\mathrm{CH}_{2} \mathrm{O}-\right.$ $\left.\mathrm{CH}_{2} \mathrm{O}\right]^{-}\left(\mathrm{MS}^{4}\right), 232\left[\mathrm{M}-\mathrm{H}-\mathrm{H}_{2} \mathrm{O}-\mathrm{CH}_{2} \mathrm{O}-\mathrm{CH}_{2} \mathrm{O}-\mathrm{CO}\right]^{-}\left(\mathrm{MS}^{5}\right)$, confirming these substituent groups.

The HMBC spectrum of 1 showed correlations (Figure $2 \mathrm{~A}$ ) from $\delta_{\mathrm{H}} 4.61(\mathrm{H}-4)$ to $\delta_{\mathrm{C}} 107.7(\mathrm{C}-3)$, $129.0(\mathrm{C}-3 \mathrm{a}), 170.2(\mathrm{C}-5)$, and $126.0(\mathrm{C}-6 \mathrm{a})$, from $\delta_{\mathrm{H}} 8.35(\mathrm{NH})$ to $\delta_{\mathrm{C}} 68.3(\mathrm{C}-4), 170.2(\mathrm{C}-5), 50.1(\mathrm{C}-$ 6), $126.0(\mathrm{C}-6 \mathrm{a})$, and $36.3(\mathrm{C}-7)$, suggested the hydroxyl group was linked to $\mathrm{C}-4$ and the amine unit at 
C-5. The HMBC correlations from $\delta_{\mathrm{H}} 6.19,6.06$ to $\delta_{\mathrm{C}} 143.5(\mathrm{C}-1), 147.8(\mathrm{C}-2)$, from $\delta_{\mathrm{H}} 6.05,6.04$ to $\delta_{\mathrm{C}} 147.2$ (C-9), 146.9 (C-10) determined that the two methylenedioxy groups link at C-1/C-2 and C8/C-9, respectively. Furthermore, in the NOESY experiment (Figure 2B), the NOE correlations between $\mathrm{H}-4\left(\delta_{\mathrm{H}} 4.61\right)$ and $\mathrm{O}-\mathrm{H}\left(\delta_{\mathrm{H}} 5.90\right)$, between $\mathrm{H}-6\left(\delta_{\mathrm{H}} 4.50\right)$ and $\mathrm{NH}\left(\delta_{\mathrm{H}} 8.35\right)$ were observed, but no correlation was observed between H-4 and H-6 ( $\alpha$-configuration) $[2,4,5]$, suggesting that $\mathrm{H}-4$ was $\beta$-configuration and 4-OH was $\alpha$-configuration. Therefore, the chemical structure of compound $\mathbf{1}$ is elucidated as shown in Figure 1, a new natural aporphine alkaloid and named illigerine B.

Furthermore, the three known compounds were isolated and identified as laurodionine B (2), $\mathrm{N}$ formyl-laurolitsine (3) and illigerine A (4) [6] base on the NMR and MS data and corresponding with those from literatures.

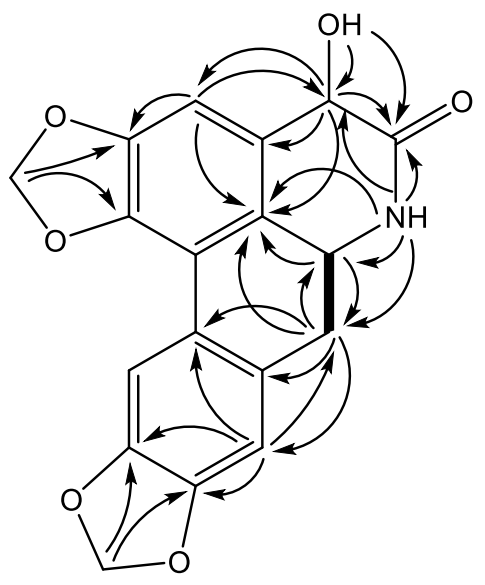

A

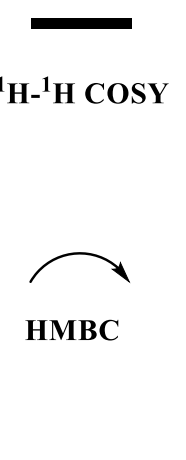

Figure 2. The selective key HMBC (A) and NOESY (B) correlations of compound 1

Table 1. NMR data of compound 1 (at $600 \mathrm{MHz}$ in DMSO- $d_{6}, \delta$ in ppm, $J$ in $\mathrm{Hz}$ )

\begin{tabular}{|c|c|c|c|}
\hline Position & $\delta_{\mathrm{C}}(\mathbf{p p m})^{\mathrm{ab}}$ & $\delta_{H}(\mathbf{p p m})^{\mathrm{c}}$ & HMBC $^{d}$ \\
\hline 1 & $143.5(\mathrm{C})$ & - & - \\
\hline $1 \mathrm{a}$ & $115.3(\mathrm{C})$ & - & - \\
\hline 2 & $147.8(\mathrm{C})$ & - & - \\
\hline 3 & $107.7(\mathrm{CH})$ & $6.85(\mathrm{~s})$ & $2,4,6 a$ \\
\hline $3 a$ & $129.0(\mathrm{C})$ & - & - \\
\hline 4 & $68.3(\mathrm{CH})$ & $4.61(\mathrm{~d}, J=5.90)$ & $3,3 a, 5,6 a$ \\
\hline 5 & $170.2(\mathrm{C})$ & - & - \\
\hline 6 & $50.1(\mathrm{CH})$ & $4.50(\mathrm{dd}, J=5.20,14.15)$ & $6 a, 7$ \\
\hline $6 a$ & $126.0(\mathrm{C})$ & - & - \\
\hline 7 & $36.3\left(\mathrm{CH}_{2}\right)$ & $\begin{array}{l}2.56(\mathrm{dd}, J=14.15,14.55) \\
3.04(\mathrm{dd}, J=5.20,14.55)\end{array}$ & $6,6 a, 7 a, 8,11 a$ \\
\hline $7 \mathrm{a}$ & $128.7(\mathrm{C})$ & - & - \\
\hline 8 & $109.5(\mathrm{CH})$ & $6.97(\mathrm{~s})$ & $7,11 \mathrm{a}, 9,10$ \\
\hline 9 & $147.2(\mathrm{C})$ & - & - \\
\hline 10 & $146.9(\mathrm{C})$ & - & \\
\hline 11 & $107.0(\mathrm{CH})$ & $7.52(\mathrm{~s})$ & $1 \mathrm{a}, 7 \mathrm{a}, 9,10$ \\
\hline $11 \mathrm{a}$ & $124.0(\mathrm{C})$ & - & - \\
\hline$-\mathrm{OCH}_{2} \mathrm{O}-$ & $101.7\left(\mathrm{CH}_{2}\right)$ & $6.19(\mathrm{~s}), 6.06(\mathrm{~s})$ & 1,2 \\
\hline$-\mathrm{OCH}_{2} \mathrm{O}-$ & $101.8\left(\mathrm{CH}_{2}\right)$ & $6.04(\mathrm{~s}), 6.05(\mathrm{~s})$ & 9,10 \\
\hline$-\mathrm{NH}$ & - & $8.35(\mathrm{~s})$ & $4,5,6,6 a, 7$ \\
\hline$-\mathrm{OH}$ & - & $5.90(\mathrm{~d}, J=5.90)$ & $3 a, 4,5$ \\
\hline
\end{tabular}

${ }^{a}$ Recorded at $125 \mathrm{MHz} ;{ }^{b}$ Multiplicities inferred from DEPT and HSQC experiments;

${ }^{c}$ Recorded at $500 \mathrm{MHz} ;{ }^{d}$ Proton showing long range correlation with indicated carbons. 


\subsection{Cytotoxicity Activity}

Compound 1 exhibited moderate cytotoxic activity against the three tumor cell types, with $\mathrm{IC}_{50}$ values of $12.40 \pm 0.78,32.61 \pm 2.05$, and $28.69 \pm 1.80 \mu \mathrm{g} / \mathrm{mL}$. Compounds 2 and 4 also shown moderate activity against these three tumor cell lines. Compound $\mathbf{3}$ had activity against Hela and SMMC7721 with $\mathrm{IC}_{50}$ values of $21.45 \pm 1.56$ and $18.31 \pm 2.11 \mu \mathrm{g} / \mathrm{mL}$, but no inhibit activity against Bcap37 $\left(\mathrm{IC}_{50}>40 \mu \mathrm{g} / \mathrm{mL}\right)$.

Table 2. Cytotoxic effects of compounds 1-4 against tumor cell lines (72h)

\begin{tabular}{l|lll}
\hline \multirow{2}{*}{ Compound } & \multicolumn{3}{|c}{ IC $\mathbf{5 0}(\boldsymbol{\mu g} / \mathbf{m L}) \pm$ SD } \\
& Hela & SMMC7721 & Bcap37 \\
\hline Illigerine B (1) & $12.40 \pm 0.78$ & $32.61 \pm 2.05$ & $28.69 \pm 1.80$ \\
Laurodionine B (2) & $11.77 \pm 1.02$ & $20.83 \pm 1.80$ & $32.89 \pm 2.84$ \\
$N$-formyl-laurolitsine (3) & $21.45 \pm 1.56$ & $18.31 \pm 2.11$ & $>40$ \\
Illigerine A (4) & $18.39 \pm 2.06$ & $15.62 \pm 1.75$ & $38.21 \pm 4.27$ \\
DDP (Positive control) & $5.70 \pm 0.37$ & $6.40 \pm 0.41$ & $8.90 \pm 0.57$ \\
\hline
\end{tabular}

We reported the isolation, chemical structure characterization and cytotoxic activity of the new aporphine alkaloid, illigerine B (1). This work demonstrated that aporphine alkaloids are typical bioactive compounds of the genus Illigera, and might be useful as characteristic markers in chemotaxonomic research.

\section{Acknowledgments}

This work was supported by Zhejiang Provincial Collaborative Innovation Center of Food Safety and Nutrition (No. 2017SICR110) and the open fund of Jiangsu Key Laboratory of Regional Resource Exploitation and Medicinal Research (LPRK201801).

\section{Supporting Information}

Supporting information accompanies this paper on http://www.acgpubs.org/journal/records-ofnatural-products

\section{ORCID}

Kuiwu Wang: 0000-0002-9778-4520

Xiaoxin Wang: 0000-0003-1590-5542

Haijang Zhang: $\underline{0000-0002-2666-1523}$

Yichao Ge: $0000-0001-7533-6818$

\section{References}

[1] L. M. Conserva, C. A. B. Pereira and J. M. Barbosa-Filho (2005). Alkaloids of the Hernandiaceae: Occurrence and a compilation of their biological activities, The Alkaloids, vol. 54. Academic Press, San Diego, pp. 175-243.

[2] J. J. Chen, H.C. Hung, P. J. Sung, I. S. Chen and W. L. Kuo (2011). Aporphine alkaloids and cytotoxic lignans from the roots of Illigera luzonensis, Phytochemistry 72, 523-532.

[3] V. Lakshmi, K. Pandey, S. K. Mishra, S. Srivastava, M. Mishra and S. K. Agarwal (2009). An overview of family Hernandiaceae, Rec. Nat. Prod. 3(1), 1-22.

[4] K. S. Chen, Y. C. Wu, C. M. Teng, F. N. Ko and T. S. Wu (1997). Bioactive alkaloids from Illigera luzonensis, J. Nat. Prod. 60, 645-647.

[5] I. S. Chen, J. J. Chen, C. Y. Duh, I. L. Tsai and C. T. Chang (1997). New aporphine alkaloids and cytotoxic constituents of Hernandia nymphaeifolia, Planta Med. 63,154-157.

[6] Y. C. Ge, H. J. Zhang, K. W. Wang and X. F. Fan (2018). Aporphine alkaloids from Illigera aromatica from Guangxi Province, China, Phytochemistry 154, 73-76. 
[7] J. W. Dong, L. Cai, X. J. Li, J. P. Wang, R. F. Mei and Z. T. Ding (2017). Monoterpene esters and aporphine alkaloids from Illigera aromatica with inhibitory effects against cholinesterase and NO production in LPS-stimulated RAW264.7 macrophages, Arch. Pharm. Res. 40(12), 1394-1402.

[8] Flora of China Editorial Committee (2008). Flora of China, vol. 7. Science Press, Beijing, pp. 255-260.

[9] Z. F. Guo, X. B. Wang, J. G. Luo, J. Luo, J. S. Wang and L. Y. Kong (2011) A novel aporphine alkaloid from Magnolia officinalis, Fitoterapia 82, 637-641.

[10] K. W. Wang, D. Li, B. Wu and X. J. Cao (2016). New cytotoxic dimeric and trimeric coumarins from Chimonanthus salicifolius, Phytochem. Lett. 16, 115-120.

[11] Y. C. Ge, Y. C. Cheng, K. W. Wang and H. Wang (2017). Unusual 28, 29-nor-9, 19 cycloartane triterpenoids from Chinese medical plant Streptocaulon griffithii Hook, Phytochem. Lett. 22, 185-188.

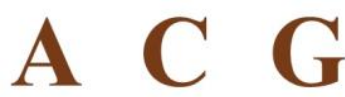

publications

(C) 2019 ACG Publications 